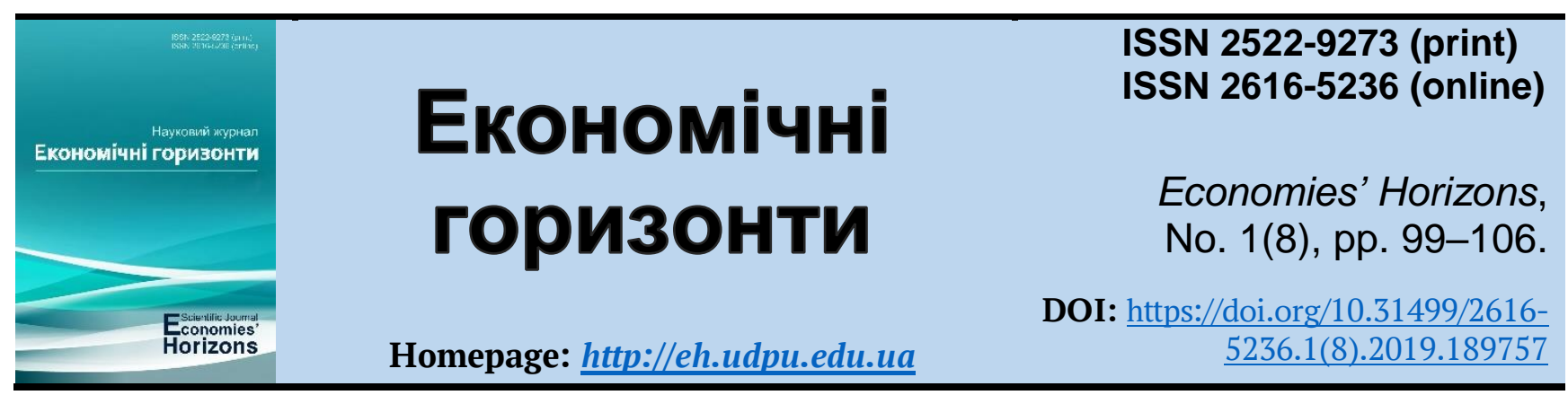

UDC 658.5:33-049.5

\title{
Study of economic development reserves of the hotel enterprises and restaurant industry under the systems analysis method
}

\author{
Olena I. Judina ${ }^{1}$, Cand. Ec. Sc. \\ Halyna A. Ryzhkova ${ }^{2}$, Cand. Ec. Sc., Associate Professor \\ Received: 18 February 2019 \\ Judina, O. I. and Ryzhkova, H. A. (2019), "Study of economic development reserves of \\ the hotel enterprises and restaurant industry under the systems analysis method", \\ Accepted: 20 March 2019 \\ Economies' Horizons, no. 1(8), pp. 99-106, doi: https://doi.org/10.31499/2616- \\ $\underline{5236.1(8) .2019 .189757 .}$
}

\begin{abstract}
The purpose of the research. The purpose of this paper is the determination based on the method of system analysis of reserves of economic development of the enterprises of hotel and restaurant services by constructing multiple regression models of industrial and commercial activities and calculation on the basis of factors that characterize development reserves resource potentials and directions of growth of efficiency of business entities. Methodology. The methodology is based on the fundamentals of business Economics, econometrics, mathematical statistics, and publications of domestic and foreign scientists on the problems of economic development of enterprises. To identify, assess and substantiate the results of the study used methods of theoretical justification, grouping, economic-mathematical modeling, factorial, statistical, stochastic, correlation and regression analysis, etc. Results. In the work on the basis of the objective function the model of multiple regression of industrial and commercial activities, which mathematically described the communication patterns and quantitative relationships of its elements (factors or input intensities), defined a differentiated and integrated the impact of costs of operating activities on the profitability of hotel and restaurant management. By calculating $\beta_{K i}$-coefficients set share changes standard deviation values of the resultant variable due to changes in relevant economic indicators regression equation on the value of its standard deviation. According to the calculated $\beta_{\mathrm{Ki}^{-}}$ coefficients that characterize the degree of a variation factor parameter defined by reserves economic development and possibilities of improving the productive performance of enterprises, as reflected in economic and mathematical models. It is proved that the increase in the costs of labor resource development and administrative expenses increases the level of income of the enterprise, and the increase of material costs and expenses on the basic production funds have a negative impact on the efficiency of functioning and, consequently, the development of economic entities. It has also been found that the largest reserves for raising the income level of the hotel and restaurant business are laid down in the cost of OVF and administrative and marketing activities. Practical meaning. The proposed research method-
\end{abstract}

\footnotetext{
${ }^{1}$ Higher Education Private Institution "Dnipro Humanitarian University"; Head of the Department of Hotel and Restaurant Business; ORCID ID: https://orcid.org/0000-0003-3699-5321; e-mail: el.judina@gmail.com.

2 Higher Education Institution "Alfred Nobel University"; Associate Professor at the Department of Entrepreneurship, Trade and Exchange; ORCID ID: https://orcid.org/0000-0002-2874-1797; e-mail: gryzhkova@gmail.com.
} 
ology was used in forecasting and planning the results of the enterprises. The prospects for further research are to identify trends and to form an effective mechanism for sustainable economic development of hotel and restaurant businesses.

Keywords: enterprise, economic development reserves, system analysis, management efficiency.

JEL Classification: C55, O12, O14, Z32.

Number of references: 10; number of tables: 0; number of figures: 0; number of formulas: 4.

\section{Дослідження резервів економічного розвитку підприємств готельно- ресторанного господарства методом системного аналізу}

Стаття надійшла: 18.03 .2019 Стаття прийнята: 20.04.2019

\section{О. І. Юдіна ${ }^{1}$, к. е. н.}

\author{
Г. А. Рижкова ${ }^{2}$, к. е. н., доцент
}

Judina O. I., Ryzhkova H. A. Study of economic development reserves of the hotel enterprises and restaurant industry under the systems analysis method. Економічні горизонти. 2019. № 1(8). C. 99-106. DOI: $\underline{10.31499 / 2616-}$ 5236.1(8).2019.189757.

Анотація. Мета дослідження. Метою статті $є$ визначення на основі методу системного аналізу резервів економічного розвитку підприємств готельно-ресторанного господарства шляхом побудови моделі множинної регресії виробничо-комерційної діяльності та розрахунку на їі основі коефіцієнтів, що характеризують резерви розвитку ресурсних потенціалів і напрями зростання ефективності суб’єктів господарювання. Методологія. Методологія дослідження базується на фундаментальних положеннях економіки підприємства, економетрики, математичної статистики, а також публікаціях вітчизняних і зарубіжних учених з проблематики економічного розвитку підприємств. Для визначення, оцінки та обгрунтування результатів дослідження використано методи теоретичного обгрунтування, групування, економікоматематичного моделювання, факторного, статистичного, стохастичного, кореляційнорегресійного аналізу та ін. Результати. У роботі на основі функції цілі побудовано модель множинної регресії виробничо-комерційної діяльності, за допомогою якої математично описано закономірності взаємодії та кількісного взаємозв'язку їі складових елементів (факторів впливу або показників витратомісткості), визначено диференційований та інтегрований вплив витрат 3 операційної діяльності на рівень доходності підприємства готельно-ресторанного господарства.

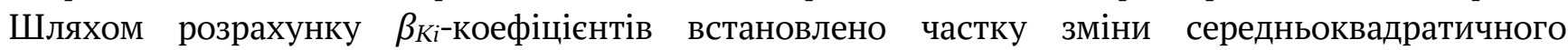
відхилення значення результативної ознаки за рахунок зміни відповідного економічного показника регресійного рівняння на величину його середньоквадратичного відхилення. За

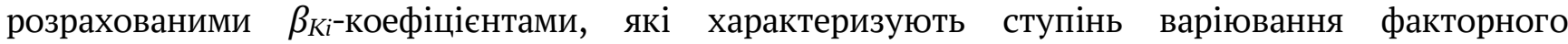
параметра, визначено резерви економічного розвитку і встановлені можливості щодо поліпшення результативного показника діяльності підприємства, відображеного в економіко-математичній моделі. Доведено, що збільшення витрат на розвиток ресурсу праці й витрат на адміністративнозбутову діяльність підвищують рівень доходу підприємства, а зростання матеріальних витрат і витрат на основні виробничі фонди надають негативного впливу на ефективність функціонування, а отже, і розвиток суб’єктів господарювання. Також встановлено, що найбільш

\footnotetext{
${ }^{1}$ Вищий навчальний приватний заклад «Дніпровський гуманітарний університет»; завідувач кафедри готельно-ресторанного бізнесу; ідентифікатор ORCID: https://orcid.org/0000-0003-3699-5321; e-mail: el.judina@gmail.com.

${ }^{2}$ Вищий навчальний заклад «Університет імені Альфреда Нобеля»; доцент кафедри підприємництва, торгівлі та біржової діяльності; ідентифікатор ORCID: https://orcid.org/0000-0002-2874-1797; e-mail: gryzhkova@gmail.com.
} 
крупні резерви підвищення рівня доходу підприємств готельно-ресторанного господарства закладені у витратах на ОВФ і адміністративно-збутову діяльність. Практичне значення. Запропоновану методологію дослідження використано у прогнозуванні та плануванні результатів діяльності підприємств. Перспективи подальших досліджень полягають у встановленні трендів і формуванні ефективного механізму сталого економічного розвитку підприємств готельно-ресторанного господарства.

Ключові слова: підприємство, резерви економічного розвитку, системний аналіз, ефективність управління.

Кількість джерел: 10; кількість таблиць: 0; кількість рисунків: 0; кількість формул: 4.

\section{Introduction.}

Reserves of economic development of the enterprise are a complex concept, as well as the economic activity itself, because they depend on the availability of resources, efficiency of their use and management of economic systems. The efficient increase through the reserves contributes to the economic growth of any enterprise.

Target setting. Therefore, in order to ensure the economic development of economic entities, it is necessary to establish the influence patterns of existing internal reserves on the profitable level of enterprises for the development of their resource potentials. In the modern conditions of the hotel and restaurant business management, the solution of these issues becomes especially relevant and is an important scientific and practical task.

\section{Literature review.}

The study of scientific works in the field of internal enterprise reserves and their impact on economic development showed that presently insufficient attention has been paid to these issues when researching the enterprise activity in the field of hotel and restaurant management. The issue of economic development of enterprises was studied by such many scientists as: S. Mochernyi (2002), V. Vasilenko (2005), S. Borodich (2010), Ju. Gavrilec (2010), B. Andrushkiv, Yu. Vovk and E. Vovk (2012), V. Gluhov, S. Korobko and M. Mednikov (2012), F. Zinoviev (2012), O. Balakirieva (ed.), O. Shestakovskyi (ed.) et al. (2014), I. Liberman (2016) and others.
In the work of B. Andrushkiv, Yu. Vovk and E. Vovk (2012) the possibilities of reducing the resource intensity of production are investigated and some directions of economic growth are determined at the expense of rational resources use. V. Vasilenko (2005) considers the dynamics of the environment, which includes a variety of forms and ways of development and identifies the individual components, namely the structural units of the enterprise, which effective management can provide economic development as irreversible, regular changes through the use of the organizational system of management reserves. O. Balakirieva (ed.), O. Shestakovskyi (ed.) et al. (2014), S. Borodich (2010), Ju. Gavrilec (2010), V. Medvedev (2010), I. Liberman (2016) the need of long-term use of labor resource reserves and the productive forces development, as a major factor of economic growth and development. S. Mochernyi (2002) defines economic development as irreversible, regular changes in the technological mode of production. F. Zinoviev (2012) pays attention to the economic development, which is ensured by identifying the influence centers and analysis of interrelations between the structural elements of the system, which allows to identify the directions of the organizational system development in the long-term interval as the main factors of economic development of enterprises.

At the same time, there is no systematic approach in the research, on the basis of which the reserves of resource potentials of economic 
growth of enterprises are established and calculated. They will allow to effectively manage any unit of the hotel and restaurant industry.

\section{Methods.}

In order to study the features, conditions and patterns and to establish reserves for the economic efficiency growth of hotel enterprises, and, consequently, sustainable economic development, the systems analysis method was used in the research, which includes:

- structural approach - the selection of structural elements of the system;

- functional approach -the need to study the functions of each element (process or activity) of the system;

- genetic approach - isolation of influence factors (centers) in the studied system and determination of their effect on the development of the whole structure of elements of this system;

- integration approach - investigation of interrelation between structural elements of the system and identification of general trends in the system development as a whole entity (Zinoviev, 2012, pp. 4-5).

In addition, the theoretical justification method, the grouping method, as well as methods of factor, statistical, stochastic, correlation-regression analysis etc. are used within the framework of these approaches.

The proposed research method provides an opportunity to study the properties of each functional unit of the enterprise, the process and direction of activity on the basis of the target function, to adequately assess their status, mutual impact and effect on the general result, as well as to analyze the possible effects of factors of internal and external environment, both on the efficiency of work and economic development of the enterprise as a whole and its components separately.

\section{Research objectives.}

Determination on the basis of the systems analysis method of the hotel and restaurant industry economic development reserves by developing a model of multiple regression of production and commercial activity and calculating the coefficients characterizing the reserves of resource potentials development and directions of increasing the efficiency of economic entities.

\section{Results and discussions.}

A hotel and restaurant enterprise is a social and economic entity where a human factor or a labor factor plays an important role. Since such organizational structures are complex systems, it is necessary to consider individual elements without their separation from the properties and dynamics of a holistic system. The following properties are typical for the enterprise as a system:

- structural and functional complexity, which manifests itself in a large number of possible states;

- the presence of relations - the interdependence of the processes and phenomena separated in space and (or) in time, reflecting causes and effects;

- dynamics, which is manifested in the reactions to changes and actions of the environment, as well as in the structural and functional remodeling by the development of individual storehouses (subsystems) and structural units of the enterprise;

- qualitative heterogeneity, which is manifested in the fact that subsystems with qualitatively different control signals, in particular the informational ones, function jointly and harmoniously within the same functional system.

- hierarchy is characterized by a constant complication of functions at one level of the hierarchy and a rapid transition to a qualitatively different function at the next hierarchy level;

- structural and functional organization is manifested at all hierarchical levels of subsystems and is characterized by high form stability, uniformity of constituent elements and subsystems;

- structural and functional stochasticity is functionally manifested in a semi-functionality, variety of reactions to the same environmental actions and signals of subsystems. It means that the systems can achieve their goals 
using different inputs and different internal activity, and the same environment can contain different forms and ways of development;

- structural discretion without which functional continuity is impossible, that is, variability of quantitative parameters within one discretion (Vasilenko, 2005, pp. 167-168).

The target function allows to express the quality of constituent elements of the enterprise as a system (subsystem), any process in relation to other evaluated criteria, in a mathematical form.
With the help of the target function the model of multiple regression of production and commercial activity was developed. It is the basis for mathematical description of the interaction patterns and quantitative correlation of its elements (factors of impact or cost indices), to determine their differentiated and integrated impact on the profitability level of the restaurant and hotel industry of Dnipropetrovsk region, as well as reserves of resource potential development:

$$
\hat{G}_{P P C}=1,54948-0,75545 \times \bar{K}_{M C P}+2,93728 \times \bar{K}_{L I V}-10,9558 \times \bar{K}_{C I V}+1,67489 \times \bar{K}_{O E L},
$$

where $\hat{G}_{P P C}$ - the theoretical (expected) value of the profitability level of the enterprise activity under the influence of factors of production and commercial activity of the enterprise;

$\bar{K}_{M C P}$ - average value of material consumption of production (factor of material expenses);

$\bar{K}_{L I V}$ - average labor intensity value of the enterprise (labor cost factor);

$\bar{K}_{C I V}$ - average capital intensity value (factor of main fixed assets costs);

$\bar{K}_{O E L}$ - average value of other operating expenses level.

The calculated coefficients for the influencing factors of the developed economic and mathematical model show how on average the value of the productive sign changes with the increase of the factor one by the own measurement unit, respectively, the calculated parameters value under the influencing economic indices, varies depending on the measurement units.

However, on the basis of regression coefficients it is impossible to determine which of the factors has the greatest impact on the effective sign, as well as in the development of which influencing factors, the greatest level of reserve change in the performance of the enterprise is laid, since the regression coefficients do not take into account the variation of factor signs, that is the standardized estimation of the statistical values deviation of the factors from their average value.

To determine the reserves of economic development and opportunities to improve the effective index of the enterprise, reflected in the economic and mathematical model, under the influence of a specific, separately taken factor parameter, it is necessary to take into account the differences in their degree of variation by calculating $\beta_{K i}$ coefficients. These coefficients allow you to determine what part of the standard deviation changes the value of the effective sign by changing the corresponding economic index of the regression equation by the value of its root-mean-square deviation, and are calculated by the formula:

$$
\beta_{K i}=a_{K i} \frac{\overline{\sigma_{K l}}}{\overline{\sigma_{G_{K l}}}}
$$

where $\beta_{K i}$ is the standardized coefficient of the multiple regression model;

$a_{K i}$ is a coefficient of the $i$-th factor in the multiple regression model;

$\overline{\sigma_{K_{l}}}$ is a root-mean-square deviation of the $i$-th factor;

$\overline{\sigma_{G_{K l}}}$ is a root-mean-square deviation of the effective sign.

Thus, the coefficients of the obtained multiple regression equation are standardized by calculating the ratio of the root-mean-square 
deviations of the influencing and effective economic indices, and are used instead of the original variables. And if the $\beta_{K i}$ coefficient is positive, then the relationship of this and the dependent variable is positive, and if it is negative, then the relationship is negative.

The root-mean-square deviation of the productive characteristic $G_{K i}$ from the equalized values $\overline{G_{K i}}$ is calculated by the formula:

$$
\sigma_{\mathrm{G} K i}=\sqrt{\frac{\sum\left(G_{K i}-\bar{G}_{K i}\right)^{2}}{n}},
$$

where $\sigma_{G_{K i}}$ is the root-mean-square deviation of the effective sign;

$G_{K i}$ is the effective sign;

$\overline{G_{K i}}$ is the equalized (average) values of the productive characteristic $G_{K i}$.

The mathematical formula for determining the root-mean-square deviation of the factor sign $K_{i}$ of its average value $\overline{K_{i}}$ is:

$$
\sigma_{K i}=\sqrt{\frac{\sum\left(K_{i}-\overline{K_{i}}\right)^{2}}{n}},
$$

or

$$
\sigma_{K_{i}}=\sqrt{\frac{\sum K_{i}^{2}}{n}-\left(\frac{\sum \overline{K_{i}}}{n}\right)^{2}}
$$

1) for the expected rate of return:

$$
\sigma_{\mathrm{G}_{P P C}}=\sqrt{\frac{\sum\left(G_{P P C}-\bar{G}_{P P C}\right)^{2}}{n}}=\sqrt{0.00539}=0.07342 ;
$$

2) for the index of the material expenses level:

$$
\sigma_{K_{M C P}}=\sqrt{\frac{\sum\left(K_{M C P}-\bar{K}_{M C P}\right)^{2}}{n}}=\sqrt{0.00381}=0.058114 ;
$$

3) for the index of the labor expenses level:

$$
\sigma_{K_{L V V}}=\sqrt{\frac{\sum\left(K_{L V}-\bar{K}_{L V}\right)^{2}}{n}}=\sqrt{0.0011095}=0.033309 ;
$$

4) for the index of the main fixed assets expenses level: 


$$
\sigma_{K_{C V}}=\sqrt{\frac{\sum\left(K_{C I V}-\bar{K}_{C I V}\right)^{2}}{n}}=\sqrt{0.000162}=0.01272 ;
$$

5) for the index of other operating expenses level:

$$
\sigma_{K_{O E L}}=\sqrt{\frac{\sum\left(K_{O E L}-\bar{K}_{O E L}\right)^{2}}{n}}=\sqrt{0.00462}=0.06794 .
$$

Thus, the smaller the standardized estimate of the statistical values deviation of the factors from its average value, the greater is the stability of the economic index.

On the basis of the acquired values of the differentiated standard deviations of the model, the level of change of the root mean square deviation of the effective sign under the influence of the factor change on the value of its root mean square deviation is determined. This evaluation characteristic has the designation $\beta_{K i}$ and is determined by the formula (2):

1) for the index of the material expenses level:

$$
\begin{aligned}
\beta_{\mathrm{K}_{M C P}} & =-0.75545 \frac{0.058144}{0.07342}= \\
& =-0.5982 ;
\end{aligned}
$$

2) for the index of the labor expenses level:

$$
\beta_{\mathrm{K}_{L I V}}=2.93728 \frac{0.033309}{0.07342}=1.332 \text {; }
$$

3) for the index of the main fixed assets expenses level:

$$
\beta_{\mathrm{K}_{C I V}}=-10.9558 \frac{0.01272}{0.07342}=-1.89777 \text {; }
$$

4) for the index of other operating expenses level:

$$
\beta_{\mathrm{K}_{O E L}}=1.67489 \frac{0.06794}{0.07342}=1.54992 .
$$

The analysis of standardized economic indices of this model shows that under the standard deviation of the material costs level by 0,058144 un., the labor expenses level by 0,033309 , the main fixed assets expenses level by 0.01272 and the other operating expenses level by 0.06794 , the level of profitability of the enterprise will change to $(-0.5982) ; 1.332$; $(-1.89777)$ and 1.54992 un., respectively. It has to be considered that the increase in the values of labor expenses factor and costs for administrative and marketing activities increase the rate of enterprise return, and the increase in material expenses and fixed assets expenses reduce it and vice versa. In addition, these calculations show that the factors in the development of which the largest reserves of enterprise income increase are laid, include the fixed assets costs $\left(\beta_{K_{C I V}}=1.9\right)$ and the cost of administrative and marketing activities $\left(\beta_{\mathrm{K}_{O E L}}=1.55\right)$.

\section{Conclusions.}

Since the enterprise is a complex social and economic system, some of its elements were analyzed without the separation from the properties and dynamics of a system as a whole. Determination of reserves of factor parameters economic development as the elements of production and commercial activity, allows to establish the level and directions of increase of efficiency of functioning and development of hotel and restaurant enterprises. By developing the model of multiple regression of production and commercial activity in mathematical form, using the objective function, the regularities of interaction and quantitative interrelation of its elements are described, namely their differentiated and integrated influence on the profitability level of the enterprise of the hotel and restaurant industry of Dnipropetrovsk region as well as their resource potentials.

According to the calculated $\beta_{K i}$ - coefficients, which characterize the degree of the 
factor parameter variation, the reserves of economic development were developed and the opportunities to improve the performance indicator of the enterprise, reflected in the economic and mathematical model, were set.

Analysis of the standardized economic indices of this model showed the interdependence of the enterprise profitability level at $(-0.5982) ; 1.332 ;(-1.89777)$ and 1.54992 units when the standard deviation of the material costs level by 0.058144 units, the labor costs level by 0.033309 , the main fixed assets expenses level by 0.01272 and other operating expenses level by 0.06794 .

The obtained results show that the increase in the costs of labor resource development and the costs of administrative and marketing activities increase the level of in- come of the enterprise, and the increase of material costs and expenditures on the basic production funds have a negative impact on the efficiency of functioning and, thus, the development of economic entities. It has also been established that the largest reserves for raising the income level of the enterprises of hotel and restaurant industry are laid down in the costs of fixed assets and administrative and marketing activities.

The coefficients that characterize the opportunities for economic growth and reserves of development of economic entities, determined by the method of systematic analysis, become the basis for further research of current trends and the formation of an effective mechanism for sustainable economic development of the enterprises of hotel and restaurant industry.

\section{References}

Andrushkiv, B. M., Vovk, Yu. Ya. and Vovk, E. P. (2012), Resursonomika: teoretichni ta pricladni aspekti [Resource economics: theoretical and applied ASPECTS], Terno-graf, Ternopil, Ukraine, 456 p.

Balakireva, O. M. (ed.), Heiets, V. M., Holovakha, Ye. I., Holovenko, V. A., $\quad$ Levin, R. Ya. and Shestakovskyi, O. P. (ed.) (2014), Tsinnisna skladova modernizatsiinykh protsesiv u suchasnomu sotsiumi Ukrainy [Value component of process modernization in the modern society of Ukraine], Instytut ekonomiky ta prohnozuvannia NAN Ukrainy, Kyiv, Ukraine, $339 \mathrm{p}$.

Borodich, S. A. (2010), Jekonometrika [Econometrics], Novoe znanie, Minsk, Belarus, 408 p.

Gavrilec, Ju. N. (2010), Celevye funkcii social'no-jekonomicheskogo planirovanija [Target functions of socioeconomic planning], Ekonomika, Moscow, Russia, 184 p.

Gluhov, V. V., Korobko, S. B. and Mednikov, M. D. (2012), Matematicheskie metody i modeli dlja menedzhmenta [Mathematical methods and models for management], Izdatel'stvo “Lan'”, St. Petersburg, Russia, 528 p.

Liberman, I. A. (2016), Upravlenie zatratami [Cost Management], MartT Publishing Center, Rostov-on-Don, Russia, $619 \mathrm{p}$.

Medvedev, V. A.(2010), Ustojchivoe razvitie obshhestva: modeli, strategii [Sustainable development of society: models, strategy], Akademija, Moscow, Russian, 312 p.

Mochernyi, S. V. (2002), Ekonomichna encyklopediia [Economic encyclopedia], Academiia, Kyiv, Ukraine, $952 \mathrm{p}$.

Vasilenko, V. A. (2005), Menedzhment ustojchivogo razvitija predprijatij [Management of sustainable development of enterprises], Centr uchebnoj literatury, Kyiv, Ukraine, 648 p.

Zinoviev, F. V. (2012), "Conceptual approach to the study of the processes of economic transformation", Economics and Management, no. 2-3. pp. 3-6.

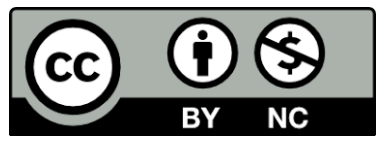

Цей твір ліцензовано на умовах Ліцензії Creative Commons «/з Зазначенням Авторства - Некомерційна 4.0 Міжнародна» (CC BY-NC 4.0). This is an open access journal and all published articles are licensed under a Creative Commons “Attribution-NonCommercial 4.0 International" (CC BY-NC 4.0). 